\title{
Analysis of export market structure for Acacia wooden furniture in Vietnam
}

\author{
Tran Thanh $\mathrm{Cao}^{1}$, Huynh Thanh $\mathrm{Nha}^{2 *}$ \\ ${ }^{1}$ Forest Science Institute of South Vietnam, Vietnam \\ ${ }^{2}$ Can Tho University of Technology, Vietnam \\ *Corresponding author: htnha@ctuet.edu.vn
}

\section{ARTICLE INFO}

DOI: $10.46223 / \mathrm{HCMCOUJS}$.

econ.en.10.2.575.2020

Received: June $30^{\text {th }}, 2020$

Revised: August $3^{\text {rd }}, 2020$

Accepted: August $15^{\text {th }}, 2020$

Keywords:

market structure, wooden furniture, Acacia wood, export
ABSTRACT
The paper aims to identify the structure of the export market for Acacia wooden furniture products, simultaneously determine the fundamentals of forming the market structure and propose marketing solutions for market development. The inequality index (GINI) and the concentration ratio (CR) were used to analyze the market structure. GINI coefficients calculated over the transaction value of sellers and buyers were 0.63 and 0.60 while the concentration ratios (CR5) were respectively $33.18 \%$ and $39.24 \%$. The results reflected the market's situation as monopolistic competition with a high concentration level from both sellers and buyers. A large population of sellers and buyers filled the market. However, economic efficiency in terms of scale was a primary barrier creating restriction when entering the market. Market development solutions include: improve capacity on design; develop standards and brands for wood materials and products; certification of goods according to international standards and regulations; restriction towards export of low-pricing products; sustain existing markets and exploit new markets; support enterprises to implement the $\mathrm{B} 2 \mathrm{C}$ trading model by Vietnamese Furniture associations; establish a specialized center of information and exhibitions for Vietnam's wooden furniture.

\section{Introduction}

In 2018, the export of wood and wood products from Vietnam reached nearly US\$ 9 billion, up $15.7 \%$ compared to 2017, being one of the 10 largest export items and accounting for $3.6 \%$ of total national export turnover (Ministry of Industry and Trade, 2019). Vietnam's wood and forest products processing industry has displayed a continuously high growth rate, averaging over 13\% per year in the period 2010 - 2018. In 2018, Vietnam's export turnover of wood products reached US\$ 8.476 billion, up $14.5 \%$ (equivalent to US\$ 1.07 billion) compared to 2017 (P. X. To, C. T. Cao, H. L. Tran, Q. T. Nguyen, \& H. V. Huynh, 2019). Vietnam's exports of wood products were ranked second in Asia and $5^{\text {th }}$ in the world in terms of export turnover, accounting for $6 \%$ of global timber market share (Prime Minister, 2019).

The Prime Minister issued Directive No. 08/CT-TTg on March 28, 2019, on solutions for the fast and sustainable development of export wood and non-timber forest products processing industry. In particular, the goals were increases in the export turnover of wood and non-timber 
forest products to US\$ 11 billion in 2019, 12 billion US\$ by 2020, 18 to 20 billion US\$ by 2025; and a gradual increase of the share of export of highly processed products with Vietnamese brands. Promoting plantations for timber and wood raw material and supplying certification of sustainable forest management as required by the International market are the important tasks of this Directive.

Currently, Acacia is the main planted forest tree species accounting for $80 \%$ to $90 \%$ of the total plantation area in Vietnam (Ministry of Agriculture \& Rural Development, 2014). This is an important domestic source of raw materials for the wood processing industry. Vietnam Timber and Forest Product Association (VIFORES) and Information Center for Agriculture and Rural Development (AGROINFO) have annually reported on the export of timber and timber products from Vietnam. However, the detailed analysis of acacia wood products and export market structure was not mentioned. Therefore, this study was conducted to provide more information on the export market of furniture made from acacia plantation timber in Vietnam.

The purpose of this paper is to answer the following three research questions: (1) What is the export market structure of Vietnamese acacia furniture? (2) Which factors are determining the export market structure of acacia furniture in Vietnam? (3) Which solutions can be applied for developing the Vietnam export market of acacia furniture?

\section{Theoretical basis}

Market structure is an economic term used to describe the characteristics of relationships between market participants including buyers and buyers, buyers and sellers, sellers and sellers. The theory of economic competition is applied to analyze the market structure. The approach method of this study to market competition is "feasible competition". The market structure reflects the competitive power or market power of participants.

Markets are classified according to their structure, based on the levels and characteristics of competition. Key factors include the number of buyers and sellers, degree of substitution products, cost, ability to join or withdraw from the market, and degree of interdependence (Charles, 1997). Economists often characterize the levels and characteristics of competition relative to three general types: perfectly competitive markets, monopolistic competition markets, and monopoly markets (N. K. Le, 2008; Mankiw, 2011). However, many economic researchers have analyzed the structure of specific product markets broken down into four categories according to the increasing degree of monopoly as follows: (1) Perfect competition - a market with many sellers of standardized products; (2) Monopolistic Competition - there are many sellers of a differentiated product; (3) Oligopoly or group monopoly - a limited market of sellers of standardized or differentiated products; and (4) Monopoly - a market where there is only one seller with a product that has no close substitute (Charles, 1997).

The degree of competition or monopoly can be expressed through the concentration of the market calculated by different indicators. The concentration of the market is measured by the GINI coefficient and the Lorenz curve (Bukar, Mohammed, Wakawa, Shettima, \& Muhammad, 2015; Luu, 2006). If the GINI coefficient is $\mathrm{Gr}=0$, the concentration level is very low - highly competitive, the Lorenz curve is overlapping with the diagonal. If $\mathrm{Gr}=1$, the level of concentration is very high - the market is concentrated in hands of a few suppliers, the Lorenz curve is perpendicular to the perpendicular. When $0<\mathrm{Gr}<1$, the market is both competitive and monopolistic. The Concentration Ratio (CR) market share index was applied to analyze (Ismail, 2017; Luu, 2006; B. T. Nguyen, H. T. T. Hoang, \& V. D. Phan, 2015; K. V. Nguyen \& L. T. Nguyen, 2011; Pavic, Galetic, \& Piplica, 2016). According to Article 24 of Vietnam's Competition Law 2018, the CR index has 4 cases: CR2, CR3, CR4, and CR5. Herfindahl - Hirschmann Index 
(HHI) was used to assess the concentration of the market (Beck, Scott, \& Yelowitz, 2010; Ismail, 2017; Khan, Ahmad, \& Gee, 2016; B. T. Nguyen et al., 2015; K. V. Nguyen \& L. T. Nguyen, 2011; Pavic et al., 2016). According to international practice, competition authorities often classify markets according to the following bases: HHI <1,000: Markets are not centralized; $1,000 \leq \mathrm{HHI}$ $\leq 1,800$ : the level of market concentration is moderate; HHI > 1,800: the level of market concentration is high. The Lerner Index is a direct measure of market power. The Lerner index ranges from a low value of 0 to a high of 1 . Lerner's higher values indicate more market power and less competitive conditions (Chambers, Färe, \& Grosskopf, 2014; Khan et al., 2016; Lerner, 1934; Moyo, 2018; T. D. Nguyen, A. T. Ha, \& B. T. T. Nguyen, 2019). The Boone Index was used to measure the competitiveness of enterprises (Chambers et al., 2014; Khan et al., 2016; Leuvensteijn, Bikker, Adrian, Rixtel, \& Sorensen, 2007; Moyo, 2018). Boone Index shows that competition helps strengthen the capacity of the company's operating efficiency and weaken the ability of the company's operating inefficiency. Thus, lower profits or smaller market share are reflected.

Vietnam's export market of timber and wood products has been analyzed by several recent studies. Ministry of Industry and Trade (2019) used descriptive statistical methods to reflect the growth of Vietnam's export and import markets for timber and wood products and described simultaneously the proportion of some major markets in 2018. P. X. To et al. (2019) reported Vietnam Timber Export and Import in 2018 looked back one year using descriptive statistical methods to analyze the export and import markets of timber and wood products for Vietnam and indicated trends for 2019. The results reflected the growth of Vietnam's export and import markets for timber and timber products, described the proportions of some major markets, and gave detailed information on some key product categories as well as major raw materials for each market. The gap in the export market of timber and wood products of Vietnam has not analyzed generally yet the market structure and the market of products from Acacia wood in particular. Based on the results of market structure analysis, solutions for market development would be proposed in the coming time. For research objectives and the theory of competition, the analytical model was derived as follows:

\begin{tabular}{|c|c|c|c|}
\hline $\begin{array}{l}\text { Market structure analysis: } \\
\text { + Market concentration ratio } \\
\text { + Factors forming market } \\
\text { structure. }\end{array}$ & $\begin{array}{l}\text { Market development solutions: } \\
\text { + Product } \\
\text { + Price } \\
\text { + Place } \\
\text { + Promotion }\end{array}$ & $\rightarrow$ & $\begin{array}{c}\text { Market } \\
\text { development }\end{array}$ \\
\hline
\end{tabular}

Figure 1. The analytical framework

\section{Methodology}

\subsection{Methods of analyzing market concentration}

Descriptive statistical methods were applied to analyze product structure in this study. The criteria used include $\%$ rate, max, min, mean, mode.

The market structure was assessed through the GINI $(\mathrm{G})$ and calculated by the following formula:

$$
G=1+\frac{1}{n}-\frac{2}{n^{2} \bar{y}}\left[y_{1}+2 y_{2}+3 y_{3}+\ldots+n y_{n}\right]
$$


where $y_{1}, y_{2}, y_{3}, \ldots, y_{n}$ are the export values of $n$ enterprises sorted in descending order, $y$ is the average export value and $n$ is the number of enterprises.

In addition, the index CR (Concentration Ratio) was also used to analyze and reconcile with Article 24 of the Law on Competition year 2018 of Vietnam to assess the level of market concentration. The CR Index is calculated by the following formula:

$$
C R_{i}=\sum_{i=1}^{n} S_{i}
$$

Where $C R$ is the concentration ratio, $S_{i}$ is the market share of the enterprise which is ranked $i^{\text {th }}$ in the top of the largest enterprises; $n=2 ; 3 ; 4 ; 5$.

\subsection{Methods of analyzing the factors that shape the market structure}

The analysis method combined descriptive statistics from the collected data sources and inherited previous studies related to the export market of household wooden products of Vietnam.

Each type of market structure of a specific commodity is formed from basic factors such as the nature of the product and the characteristics of market participants.

Each type of market structure of a commodity was formed from basic elements such as the nature of the products and the characteristics of the participants in the market. Fundamentals of the market resulted in forming the structure of the market. The factors to be analyzed include:

+ Number of sellers and buyers operating in the market;

+ Concentration ratio of the enterprise showed how the largest market share was held;

+ The nature of goods and services provided to the market;

+ Differentiation of products and services of each enterprise;

+ Quantity and type of replacement goods when customers were ready to change their choice;

+ Barriers to entry or exit from a specific market;

+ Economic efficiency of scale;

+ Links between relevant stakeholders in the market to create the strength of the group.

\subsection{The method to propose market development solutions}

The proposed solutions for market development were based on the results of concentration analysis and the factors that shaped the market structure. Each commodity, every business has different tools to create a competitive advantage to develop the market. In this report, 4P integrated solutions included Product, Price, Place, and Promotion. This tool is popularly used.

\subsection{Description of data source}

The primary data was collected by a convenient method. The data was collected from 25.000 custom declarations as a part of the total data source of the General Department of Customs. Furniture code (HS code 94) and time of declarations distributed on 11 months in 2018 are two collected criteria. After that, the data tool of Microsoft Excel was used to filter out products made from wood and acacia wood. The result was 361 declarations of acacia wood furniture from the custom declarations mentioned above. The summary of the research data characteristics is presented in Table 1. 


\section{Table 1}

Information summary of research data source

\begin{tabular}{|l|c|c|}
\hline \multicolumn{1}{|c|}{ Data information } & $\begin{array}{c}\text { Total exported } \\
\text { wood Furniture }\end{array}$ & $\begin{array}{c}\text { Exported furniture } \\
\text { from acacia wood }\end{array}$ \\
\hline Number of custom declarations & 1,908 & 361 \\
\hline Number of places for custom declaration & 50 & 26 \\
\hline Number of businesses declared & 413 & 102 \\
\hline Number of commodity code (HS 94***) & 22 & 16 \\
\hline
\end{tabular}

Source: Aggregated from Vietnam Customs data source in 2018

\section{Results and discussions}

\subsection{The concentration of the market for exported furniture from Acacia wood}

\subsubsection{GINI index}

Vietnam's export market of wooden furniture operated entirely according to the market mechanism. Acacia wood is a common wood used to process many types of furniture as many other kinds of wood for exported markets. The market of wooden furniture from acacia has been participated by many businesses in the manufacturing and exporting products that were similar in usability but had differentiated features. Differences in wooden furniture could be tangible elements of the product (style, material, color, durability) and intangible differences (standard conformity, geographical location, brands, sales style, and value-added services). Since manufacturing and exporting enterprises had little monopoly benefit with their products' specific characteristics and to compete with competitors keeping similar products and substitutes, Competitive monopoly sale market was formed.

The 2018 data analysis of Vietnam Customs showed the inequality index in exported wooden furniture from acacia wood GINI $=0.63$. This index indicated that the market had a Monopolistic competition structure but deviated heavily toward monopoly.

The exported market for wooden furniture in Vietnam has been changing. Previously, Vietnamese wood processing enterprises only focused on transshipment markets such as Taiwan (China), Singapore, South Korea ... to re-export to third countries, up to now, Vietnamese wood furniture has been exported. Export directly to more than 120 countries and regions. Major markets such as the US, EU, Japan, and China are continuing to grow. Meanwhile, potential markets and new markets are also being formed (Ministry of Industry and Trade, 2019). Thus, the Vietnamese furniture market has many buyers, so it is not possible to monopolize the purchase. Analysis of the 2018 data source of Vietnam Customs showed the inequality index of imported wooden furniture from acacia wood GINI $=0.60$. Similar to exporters, the import market had a Competitive monopoly structure but deviated heavily toward monopoly. 


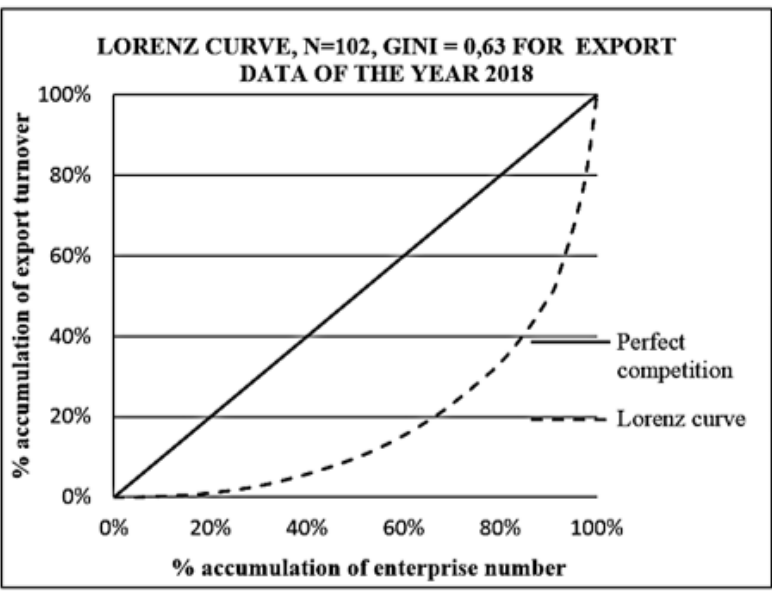

Figure 2. Lorenz curve and GINI index of export

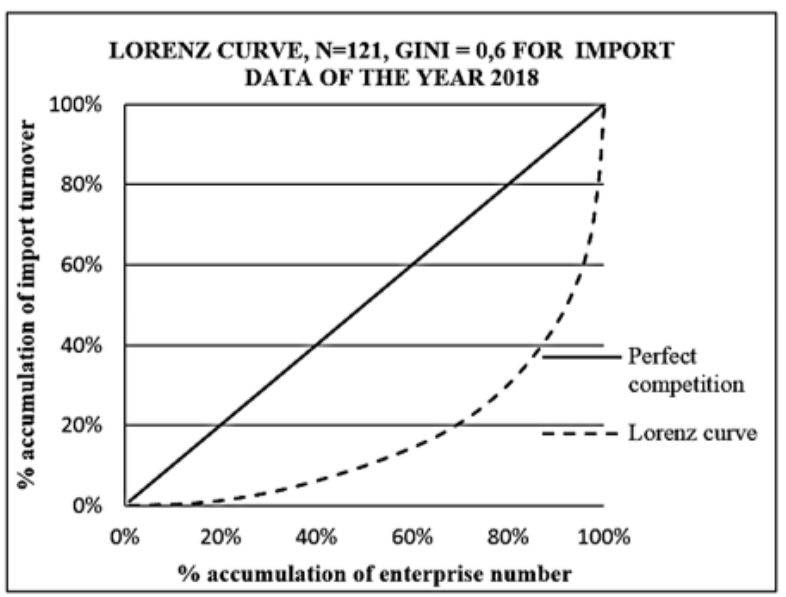

Figure 3. Lorenz curve and GINI index of export

Source: Analysis, the summary from Vietnam Customs data in 2018

\subsubsection{Concentration ratios}

In 2018, the private sector enterprises (including FDI) accounted for 95\%, the state sector accounted for $5 \%$ of the total number of wood processing enterprises in Vietnam. Small and micro, medium, and large enterprises accounted for 93\%, 5.5\%, and 1.5\%, respectively (Ministry of Industry and Trade, 2019). This data showed that most wood processing enterprises in Vietnam were small and super small. Therefore, the market focused on medium and large enterprises. According to the analysis from Vietnam Customs, the CR index of the acacia wood exported market was very high, specifically as follows: CR2 $=17.71 \%$; CR3 $=24.06 \%$; CR4 $=28.70 \%$; CR5 $=33.18 \%$. As compared with Article 24 - Competition Law year 2018 in Vietnam, the exporters of wooden furniture from acacia wood did not have a dominant market position. However, $\mathrm{CR} 10=50.10 \%$ showed that only the top 10 large enterprises have accounted for over $50 \%$ of exported market share. Like sellers, the market structure of importers was very concentrated. CR indicators for buyers of the acacia wood exported market in Vietnam were as follows: $\mathrm{CR} 2=23.81 \%$; CR3 $=30.96 \%$; CR4 $=35.28 \%$; CR5 $=39.24 \%$. Thus, enterprises importing acacia wood furniture in Vietnam did not have a dominant position in the market. However, CR10 $=50.10 \%$ indicated only the top 10 large importers have accounted for over $50 \%$ of the market share.

\subsection{Factors to form market structure}

\subsubsection{Number of sellers, buyers active in the market}

The country currently has about 4,500 businesses, processing wood, including 3,900 domestic enterprises, 600 enterprises with foreign direct investment (including mainly China and Taiwan China, Japan, Korea, EU) (Ministry of Industry and Trade, 2019). According to data from Vietnam Customs, the market had at least 412 export furniture enterprises, of which 102 enterprises were exporting acacia wooden furniture (accounting for 24.75\%). Thus, the exported market of wooden furniture from acacia wood had many sellers. But some sellers unevenly distributed among key economic regions of Vietnam. Statistics from Vietnam Customs showed that the number of enterprises participating in export accounted for $91.18 \%, 3.92 \%$ and $4.90 \%$ of total enterprises exported wooden furniture from acacia wood in the South, North, and the central, respectively. If considering each key economic region, few enterprises were participating in export in the North and Central Vietnam, which were likely to have monopoly selling. Currently, the 
number of enterprises distributed among key economic regions is not equal due to the difference in market size among regions. The Southern region accounted for 83, $12 \%$ of the market size. The Northern and Central regions respectively accounted for a small proportion of $15.34 \%$ and $1.54 \%$ of the remaining market.

According to the data of the Vietnam Customs, at least 596 importers involved the wooden furniture market in Vietnam. In which, there were 121 enterprises imported furniture from acacia wood of Vietnam (accounted for $20.30 \%$ of 596 importers). Where 6 enterprises (accounted for $5.80 \%$ ) were also exporters (the same corporation or parent company). In 2018, the acacia household wood products of Vietnam were exported to 20 countries and Vietnam export processing zones penetrated the major markets such as the US, EU, and China. Thus, the export market for acacia wood furniture had many buyers.

\section{Table 2}

The participation rate of acacia wood products in the value of exported furniture in 2018

\begin{tabular}{|c|c|c|c|}
\hline No. & Market & Product & $\begin{array}{c}\text { Participation rate in total export } \\
\text { turnover }\end{array}$ \\
\hline 1 & USA & Seat & $5 \%$ \\
\hline 2 & EU & Seat & $21 \%$ \\
\hline 3 & China & Seat & $11 \%$ \\
\cline { 2 - 4 } & & Furniture & $8 \%$ \\
\hline
\end{tabular}

Source: P. X. To et al. (2019)

\subsubsection{The nature of goods and services provided to the market}

Wooden furniture is generally both essential and luxury goods. Tables, chairs, beds, wardrobes are common items in most families. However, as these items were made of high-quality materials and designed specifically, only the rich could be able to own them. Acacia wood was a common wood that could be used to process a variety of household wooden products for the export markets. Acacia auriculiformis could replace natural forest timber, especially in high-class furniture production. The acacia wood furniture for exporting was very diverse in types, materials, and designs.

There were 22 wooden furniture categories (22 HS codes) exported from Vietnam. Where 16 acacia wooden furniture categories were recorded. This indicated the large proportion of acacia wood furniture categories of the total exported wooden furniture categories. The categories of exported wooden furniture were summarized into 7 main groups, including: 1) HS 94016 - Seats; 2) HS 94033 - Office furniture; 3) HS 94034 - Kitchen furniture; 4) HS 94035 - Bedroom furniture; 5) HS 94036 - furniture for other; 6) HS 94039 - Parts of furniture; 7) HS 94 *** - Other furniture. 


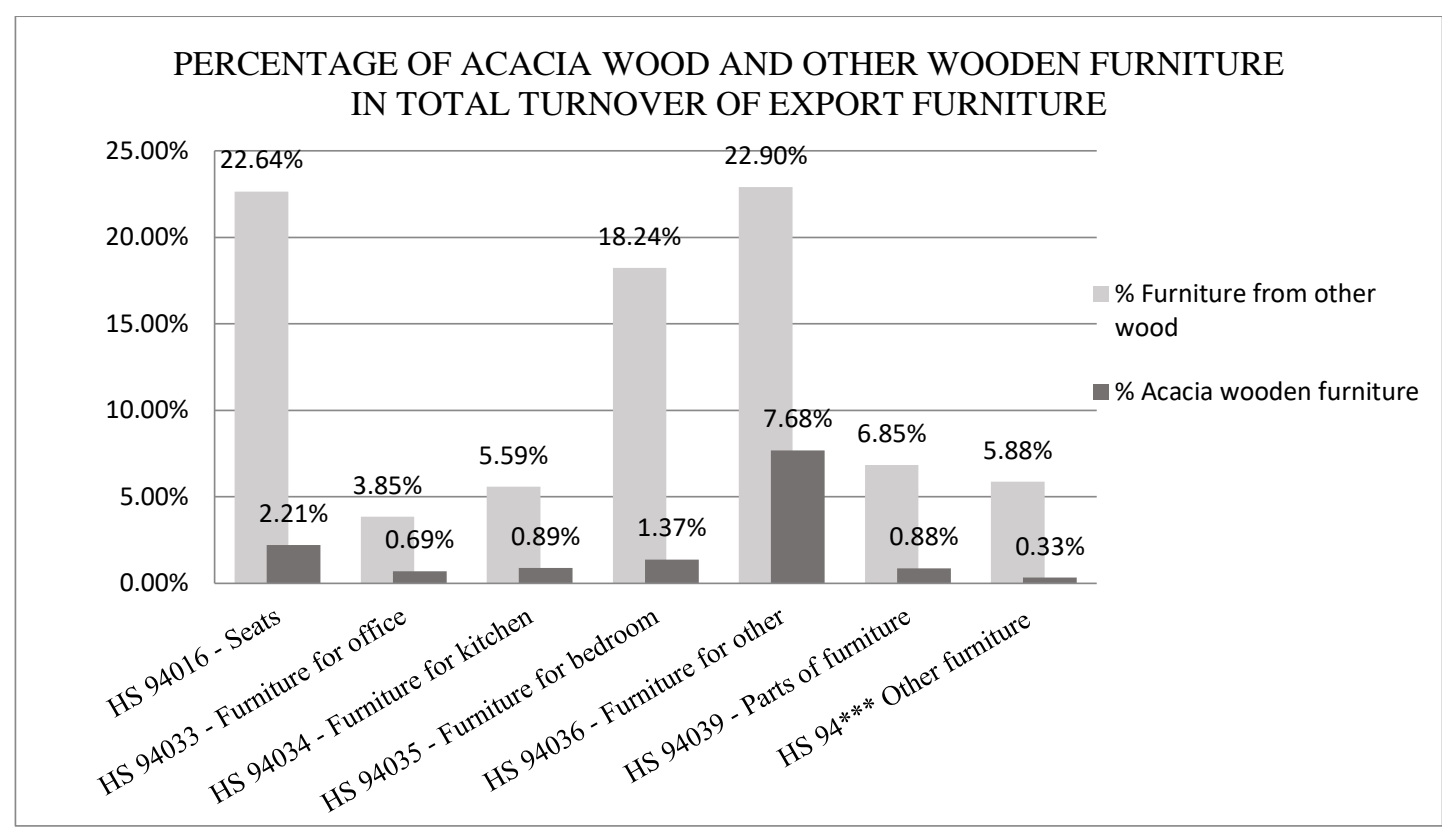

Figure 4. Participation rate of acacia and other wood in the total value of exported furniture in 2018

Source: Analysis, aggregated from Vietnam Customs data source in 2018

Seat products, bedroom furniture, and others contributed a large proportion of total exports. Acacia wood also participated in many similar types as other woods (Figure 4).

Most household wooden products were difficult to market by of e-commerce because of their bulky. Although manufacturers tried to design products that could be conveniently assembled to logistics stages, logistics costs still accounted for a high proportion of the price of goods.

\subsubsection{Product and service differentiation of enterprises}

Material diversity to produce wooden furniture was very high. In addition to the main wood material, the others including steel, aluminum, plastic, glass, mica, stone, and leather ... were also used in combination to create the main body of wooden furniture. Decorative materials and colors of furniture products were also very diverse. The abundance of materials stimulated creativity in design and created product specificity. Thus, businesses owning the design also certainly created exclusive capabilities.

In Vietnam's exported wooden furniture market, most designs were supplied by buyers, so the copyrights belonged to the importers. A small number of foreign enterprises (FDI) carried out all activities in the value chain from design, production to consumption. According to the Ho Chi Minh City Association of Fine Arts and Wood Processing (HAWA), there were about 5\% domestic designed products of Vietnam's exported wooden product group and the rest was mostly outsourced for foreign customers (H. Le, 2019). Therefore, Vietnam's wood furniture exporters have not yet got their cultural identities or foundations to build their brands. However, wooden furniture in general is also fashionable, so the designs were constantly changed. Therefore, the exclusive design of wooden furniture only exists temporarily. The abundance of product characteristics caused difficulties for consumers in comparing prices between the same similar products, so good marketing strategies are important to secure good prices.

Branding product and corporate identities were issues not noted by many wood enterprises. Some countries focused on developing brands for raw materials. Countries (the United States, Japan, and New Zealand) attached great importance to promoting timber brands to foreign markets. The American Hardwood Council cooperated with Vietnamese Wood Magazine to publish a 
special page about American hardwoods in Vietnam. Radiata pine brand of New Zealand was also quite famous. Also, the world wood market had the Hinoki wooden brand - the symbol of Japanese wood. Vietnam Acacia wood has been exported to more than 20 countries for many years but building its brand has not been invested yet. If the brand name is "Vietnam Acacia Wood", then wooden furniture from Acacia wood will make a difference.

Certification and labeling of goods in accordance with international practice created the value-added wood products on global markets. In developed countries, customers usually required a certificate of social and environmental responsibility as well as the legality of the goods as wooden furniture. The international market required wood materials to be certified for sustainable forest management - Forest Management (FM). Businesses participating in the supply chain must also be certified by the chain of product management - Chain of Custody (CoC). Besides, the requirement of legal timber origin became a mainstream trend in many markets. The US Lacey Law, the EU Forest Law Enforcement, Governance and Trade (FLEGT) Program of the EU, Australia's Anti-Illicit Logging Law are examples of this trend (P. X. To, T. T. T. Nguyen, \& D. T. T. Nguyen, 2016). However, data sources of Vietnam Customs in 2018 show that the proportion of the value of Vietnam's exported household wooden furniture from FSC - FM certified materials was very low (1.01\%). This indicated that Vietnam's wooden furniture exporting businesses was focusing on affordable markets in which high standards were not required. In particular, Acacia wooden furniture with FSC - FM certified materials had an even lower rate $(0.69 \%$ of the total value of acacia wooden furniture). This situation was due to the very small area of Acacia plantations gaining FM certification. According to updated data of FSC, up to July 2019, the total area of production forest in Vietnam certified FSC/FM was 236,990 ha $(6.8 \%$ of total plantation area?). Certification of the goods according to international rules is an issue for acacia wooden furniture at the present. Therefore, any enterprise with an FSC-FM certified timber source had market power.

Wooden furniture should generally meet the standards for raw materials. Acacia wood in Vietnam had no unified standard on markets so the quality of wooden furniture was not stable. Standard for round timber (Basic dimensions TCVN 1073-1971 and Quality classification according to defects TCVN 1074-86) and standard for lumber (term and definition of TCVN 473989; Basic dimensions TCVN 1075-1971 and Quality classification according to defect TCVN 1758-86) were the Vietnamese standards. However, these standards were built for natural forest wood in the 1970s and 1980s, so they are not for plantation timber, especially acacia wood. Meanwhile, imported sawn timber sources have clear standards. For example, the grading regulations for lumber from hardwood species of the United States by the National Association of lumber from hardwood species (NHLA) have FAS (first and second class) and F1F (FAS on one side), No.1C (popular class 1), No.2C (popular class 2), No.3C or row AB - ABC. European Oak grading - Edged wood has quality standards from QF-1 to QF-4. The lack of wood quality standards is a weakness of Vietnamese acacia wooden furniture.

\subsubsection{Quantity and types of substitutes}

There were three substituted commodities for exported acacia wooden furniture including 1) Supplies of wood products from other wood materials; 2) Goods produced with other materials; and 3) Furniture from other countries.

Vietnam's wooden products for export were usually made from acacia, rubber, other domestic plantation timber, and imported timber from legal sources. Input wood used for products exported to the EU was mainly from domestic planted timber sources (acacia, eucalyptus) and imported timber sources (oak and pine). Chairs were commodity groups with the highest turnover, which reached over US\$ 200 million in 2018. The wood types most used included acacia, pine, eucalyptus, and rubber which accounted for $21 \%, 23 \%, 8 \%$, and $5 \%$ of total exports, respectively. 
The most common timber used to make chairs for export to the United States was domestic rubber. In 2018, chairs made from rubberwood reached a turnover of US\$228.7 million and accounted for $29 \%$ of total chair exports to the US. Other woods also used to make chairs for the American market were MDF, acacia wood, and pine timber which accounted for $19 \%, 5 \%$, and $8 \%$, of total turnover respectively. In 2018, the most used timber for chairs to export to China was rubberwood (accounted for $32 \%$ of the total export turnover of this item), khaya wood (11\%), and acacia wood (11\%). The value of wooden furniture exports to China in 2018 reached US\$ 135 million. Padauk wood used popularly accounted for $40 \%$ of the total export turnover of this commodity group, followed by rubberwood (10\%) and acacia wood (8\%). Rubber, acacia, and pinewood were also the most used species for furniture and seats exported to the Korean market (P. X. To et al., 2019).

Many materials can substitute for wood to produce interior and exterior products. These materials could replace some detailed parts of a wood product or the whole product. In general, the trend of using alternative materials like aluminum, iron, glass, plastic, industrial wood, plastic wood, rattan, bamboo was gradually dominating rather than the traditional wood materials to many users. The reasons for replacing other materials for wood materials were aesthetic needs in design; the increase of wood prices; durability and ease of assembly/disassembly and transport; and consumer wishes to participate in environmental protection.

Many countries and territories are involved in the world's wooden furniture market. Other Asian countries were direct competitors of Vietnamese in wooden furniture markets, especially acacia wooden furniture. In 2017, the export market share of wooden furniture products of Asian countries to Europe were respectively China 49.8\%, Vietnam 12.2\%, Indonesia 5.3\%, Malaysia $3.2 \%$, India $3.2 \%$, Thailand $0.9 \%$ (White, 2018).

\subsubsection{Barriers to entry or exit from a market}

According to Vietnamese law, administrative procedures were not a barrier for businesses to enter or withdraw from the market. The biggest barrier for wood processing enterprises was their resources or production and business conditions.

According to Vietnam Customs data, enterprises producing and exporting acacia wood products were highly specialized, each business focused on only very few product types. Most businesses exported only one or two product types. Similar to exporters, importers also focused on a few categories of products. This phenomenon showed that businesses tried to focus their resources on increasing monopoly rather than expanding product categories.

\section{Table 3}

Enterprises grouped by the exported and imported number of acacia wood furniture categories

\begin{tabular}{|l|c|c|c|c|}
\hline \multirow{2}{*}{ Business type } & \multicolumn{2}{c|}{ Export enterprise } & \multicolumn{2}{c|}{ Import business } \\
\cline { 2 - 5 } & Number & Ratio (\%) & Number & Ratio (\%) \\
\hline Trading in 1 product category & 48 & 47 & 64 & 53 \\
\hline Trading in 2 product categories & 34 & 33 & 32 & 26 \\
\hline Trading in 3 product categories & 10 & 10 & 19 & 16 \\
\hline Trading in 4 product categories & 8 & 8 & 3 & 2 \\
\hline Trading in 5 product categories & 1 & 1 & 1 & 1 \\
\hline Trading in 6 product categories & 1 & 1 & 2 & 2 \\
\hline Total & 102 & 100 & 121 & 100 \\
\hline
\end{tabular}

Source: Analysis from Vietnam Customs data in 2018 
Moreover, export-import enterprises of acacia wooden furniture had very few partners. The analysis results from Vietnam Customs data showed that the majority of enterprises had only one or two import and export partners and a maximum of 4 partners. This indicated that the ability to expand their market was very low because of dependence on a small number of partners. At the same time, businesses were vulnerable to the failure of their partners. Thus, the firm scale was a barrier to market participation.

\section{Table 4}

Enterprises grouped by the number of import and export partners of acacia wood furniture

\begin{tabular}{|l|c|c|c|c|}
\hline \multirow{2}{*}{ Business type } & \multicolumn{2}{c|}{ Export business } & \multicolumn{2}{c|}{ Import enterprise } \\
\cline { 2 - 5 } & Amount & Ratio (\%) & Amount & Ratio (\%) \\
\hline Business with 1 partner & 75 & 74 & 111 & 92 \\
\hline Business with 2 partners & 17 & 17 & 5 & 4 \\
\hline Business with 3 partners & 8 & 8 & 4 & 3 \\
\hline Business with 4 partners & 2 & 2 & 1 & 1 \\
\hline total & 102 & 100 & 121 & 100 \\
\hline
\end{tabular}

Source: Analysis from Vietnam Customs data in 2018

Besides, an analysis of export records indicated $100 \%$ of goods consumption was sold by businesses (Business to Business - B2B). Due to the geographical distance, most of Vietnam's small and medium-scaled export enterprises were not eligible to access overseas retail markets but they had to sell their products through import enterprises.

\subsubsection{Economic effect of enterprise-scale}

Domestic plantation timber processing enterprises and small-scale furniture exporters had higher costs for production and business activities than large-scale enterprises, especially the cost of raw material purchasing and goods delivery procedures.

Domestic plantation timber in general and acacia did not have a centralized timber market, so the cost of raw materials was quite expensive. Meanwhile, there was a VITACO "Western Wood Market" for imported timber in Dong Nai, where the trade of raw wood was very favorable.

Usually, large enterprises with stable export orders will boldly sign contracts to purchase raw materials with large quantities and preferential prices and less volatility. Typically, large enterprises had stable export orders, they would confidently sign contracts for the supply of raw materials in large quantities at preferential prices, low volatility. Meanwhile, small businesses only bought raw materials when they held export contracts. At that time, businesses might have to accept the price of raw materials according to market fluctuating price and geographical distance of supply. Additionally, businesses buying origin unknown timber would also face the risk of wood quality because acacia raw materials did not have standards yet.

Normally, the logistic unit cost of large enterprises was cheaper than those of small businesses. Large enterprises had active plans in freight forwarders, so they would easily negotiate with carriers for getting lots of promotions. Besides, large quantities of goods uniform in size would easily be transported in containers with lower costs as compared with bulk shipping. 


\subsubsection{Links between relevant stakeholders on the market}

Currently, the forestry section in general and import-export activities of forest products had very few links between actors of the wood industry. In the existing models of linkage, the model of horizontal linkage aimed to create mainly raw material resources. Vertical integration of the value chain for exported wooden products was very rare. It was impossible to form a monopolistic group or a monopoly market from the current situation of linking between entities.

\subsection{Marketing solutions proposed to develop the market}

\subsubsection{Product development solutions}

There are three competitive overall strategies to increase the competitiveness of businesses. They include: 1) Cost optimization; 2) Differentiation and 3) Centralization strategy (Porter, 1985). Vietnamese enterprises in the wood processing industry in general need to participate actively in the design stage and regain design rights in the hands of buyers as at present. Some businesses are gradually changing their views from manufacturing and trading furniture products (tables, chairs) to supply interior space, which is enhancing the design value and the difference. Design activities enhance both product value and its own identity. However, the wood processing industry needs to have a common orientation that can maintain typical Vietnamese cultural traditions as well as meet the requirements of customers' utility and tastes. Especially, the unique feature of Vietnamese wooden furniture can be exploited from the characteristics of Acacia wood material.

Standards for wood and wood products from plantation forests and acacia plantation are required to ensure stability for customers. Also, international standard certification for Vietnamese wood products is also necessary to overcome the technical barriers of developed countries.

\subsubsection{Price solutions for products}

European customers recognized the difference in the prices of furniture. Vietnam was the country that supplied the lowest prices for wood furniture, followed by China, Thailand, and Indonesia. EU and Malaysia were considered the least competitive in terms of price (White, 2018). Some Vietnamese enterprises acknowledged that the current competitive price of Vietnamese wood furniture was affordable. Thus, Vietnam's timber industry could be following the wrong way as the rice sector. There have been many lessons about affordable price strategy on the market. When consumers used cheap goods, they automatically assumed that the goods were of poor quality. Some distributors also used cheap goods as promotional gifts with the main product, which accidentally reduced the quality of goods in the minds of customers. Timber industry associations need to work closely to find solutions that can limit competition by price tool and gradually increase the value of Vietnamese wood products including acacia wood products. The solution to increase the selling price can be used to improve designs, apply product standards, brand materials, and certify goods because these intangible values are difficult to be measured by customers.

When deciding on the prices of a product, suppliers need to compare their products with comparable products on the market to offer an appropriate price for both sellers and users. Although acacia is a common wood, Vietnamese businesses should target their products to middleclass customers rather than affordable customers.

\subsubsection{Solution for consuming goods}

Furniture export results in 2018 showed that some other markets continued to have growth such as Australia with a turnover of US\$ 193.1 million, up 14.1\%. Besides, some Asian markets had a strong breakthrough such as Malaysia 102.2 million US\$, up 86.2\%; Thailand 38 million 
US\$, up 49.4\%; and Saudi Arabia 27 million US\$, up 16\% (Ministry of Industry and Trade, 2019). The acacia wooden furniture export markets developed in line with other wooden export markets, maintaining the traditional market, continuing to penetrate, expand, and exploit potential markets and new markets for acacia wooden furniture are necessary.

Vietnamese furniture export enterprises need to cooperate to sell goods to consumers (Business-to-Consumer - B2C). In case, each enterprise sells its goods by B2C, the selling cost is very high. However, if many businesses cooperate, this cost will be significantly reduced. The distribution stage is profitable, but it belongs to foreign enterprises because of their advantage of scale.

Online sale is a channel that Vietnamese wood enterprises should exploit. The nature of bulky goods and geographical distance makes it difficult to deploy e-commerce to wood acacia furniture. However, if there are representative offices and warehouses in foreign countries, Vietnamese wood enterprises can sell online easily.

\subsubsection{Solution of trade promotion}

There are many solutions to trade promotion, but businesses need to consider which option can be applied and bring the highest efficiency. In today's flat world, using social networks as a tool to promote products is an effective solution that is selected by many businesses. Building specialized wood information and exhibition center to introduce products at reasonable costs is the solution that businesses can be aiming for. This solution needs supports from the State. Wood industry associations should open representative offices in major markets such as the US, Japan, Australia, and Europe to promote trade. Building up the brand of acacia wood material in Vietnam will also contribute to promoting the image of acacia wooden furniture to the world market.

\section{Conclusion}

The export markets of acacia wooden furniture were evaluated to be competitive and exclusive markets with a high degree of concentration in both buyers and sellers.

The basic factors of acacia wooden furniture export markets showed that there were many buyers and many sellers on the market. Wooden furniture was a diversified commodity, both similar in function and different in characteristics (both tangible and intangible). Businesses did not have any ability towards monopoly.

Solutions to develop markets include: businesses should enhance design capacity; State management agencies should develop standards of raw materials and products; businesses should brand for raw materials and products; businesses should improve management capacity to achieve certification according to international practices; Enterprises should restrict the export of cheap goods; Businesses should continue to maintain the traditional market and exploit new markets; Wood Industry Associations should link businesses to join the B2C model; The Government should support the Wood Industry Association to build a wooden furniture information and exhibition center in Vietnam that needs to be implemented in a synchronized manner.

\section{References}

Beck, J., Scott F., \& Yelowitz, A. (2010). Competition and market structure in local real estate markets. Retrieved October 12, 2019, from https://mpra.ub.uni-muenchen.de/27531/

Bukar, U., Mohammed, D., Wakawa, R., Shettima, B. G., \& Muhammad, S. T. (2015). Analysis of market structure, conduct and performance for pepper in Borno State, Nigeria: A review. Journal of Agricultural Economics, Environment and Social Sciences, 1, 181-190. 
Chambers, R. G., Färe, R., \& Grosskopf, S. (2014). The lerner index and economic efficiency. Theoretical Economics Letters, 4, 803-805. doi:10.4236/ tel.2014.49101.

Charles, C. F. (1997). What can economics learn from marketing's market structure analysis? Retrieved October 12, 2019, from https://www.westga.edu/bquest/1997/ecnmkt

Ismail, U. (2017). Market structures and concentration measuring techniques. Asian Journal of Agricultural Extension, Economics \& Sociology, 19(4), 1-16. doi:10.9734/AJAEES/2017/36066

Khan, H. H., Ahmad, R., \& Gee, C. S. (2016). Market structure, financial dependence and industrial growth: Evidence from the banking industry in emerging Asian economies. PLOS ONE, 11(8), Article e0160452. doi:10.1371/journal.pone.0160452

Le, H. (2019). Only 5\% of Vietnamese wooden furniture is self-designed and exported. Retrieved October 25, 2019, from https://www.thesaigontimes.vn/288494/chi-5-do-go-viet-namxuat-khau-tu-thiet-ke.html

Le, N. K. (2008). Microeconomics: Business theory and practice. Ho Chi Minh City, Vietnam: Education publisher.

Lerner, A. P. (1934). The concept of monopoly and the measurement of monopoly power. The Review of Economic Studies, 1(3), 157-175. doi:10.2307/2967480.

Leuvensteijn, M. V., Bikker, J. A., Adrian, A. R. J. M., Rixtel, V., \& Sorensen, C. K. (2007). A new approach to measuring competition in the loan markets of the Euro area (The ECB Working Paper No.768). Retrieved October 31, 2019, from the European Central Bank website: http://www.ecb.int

Luu, H. T. D. (2006). Cấu trúc thị trường tiêu thụ và hệ thống phân phối heo thịt đồng bằng sông Cửu Long [Market structure and distribution system of pork in the Mekong Delta]. Journal of Scientific Research, Can Tho University, 6, 186-195.

Mankiw, G. N. (2011). Principles of macroeconomics (6th ed.) (Department of Economics. Ho Chi Minh City University of Economics, Trans.). Hanoi, Vietnam: Cengage Learning Publishing.

Ministry of Agriculture and Rural Development. (2014). Quyết định số 774 / QD-BNN-TCLN phê duyệt kế hoạch hành động nâng cao năng suất, chất lượng và giá trị rùng trồng sản xuất giai đoạn 2014-2020 [Decision No. 774 / QD-BNN-TCLN dated April 18, 2014 on dynamic plan improving productivity, quality and value of planted production forests in the period of 2014 - 2020]. Retrieved October 31, 2019, from https://vanbanphapluat.co/quyet-dinh774-qd-bnn-tcln-nang-cao-chat-luong-rung-trong-san-xuat-2014-2020

Ministry of Industry and Trade. (2019). Vietnam export-import report 2018. Retrieved October 31, 2019, from https://wtocenter.vn/tin-tuc/13730-vietnam-import-export-report-2018\#

Moyo, B. (2018). An analysis of competition, efficiency and soundness in the South African banking sector. South African Journal of Economic and Management Sciences, 21(1), 114. doi:10.4102/sajems. v21i1.2291

Nguyen, B. T., Hoang, H. T. T., \& Phan, V. D. (2015). Đánh giá cấu trúc thị trường trong lĩnh vực ngân hàng tại Việt Nam thông qua đo lường mức độ tập trung [Evaluating the market structure in the banking sector in Vietnam by measuring the concentration level]. Banking Magazine, 16, 13-19. 
Nguyen, K. V., \& Nguyen, L. T. (2011). Cơ hội thâu tóm chuỗi giá trị toàn cầu thông qua hoạt động mua bán và sáp nhập công ty [Opportunity to acquire global value chains through mergers and acquisitions]. Journal of World Economics and Politics, 4(180), 20-25.

Nguyen, T. D., Ha, A. T., \& Nguyen, B. T. T. (2019). Cạnh tranh và ổn định hệ thống ngân hàng tại Việt Nam [Competition and stability of the banking system in Vietnam]. Retrieved October 19, 2019, from Tạp chí Ngân hàng website: http://tapchinganhang.gov.vn/canhtranh-va-on-dinh-he-thong-ngan-hang-tai-viet-nam.htm

Pavic, I., Galetic, F., \& Piplica, D. (2016). Similarities and differences between the CR and HHI as an indicator of market concentration and market power. British Journal of Economics, Management \& Trade, 13(1), 1-8. doi:10.9734/BJEMT/2016/23193

Porter, M. E. (1985). Competitive advantage. Ho Chi Minh City, Vietnam: Tre Publishing House.

Prime Minister. (2019). Chỉ thị Số 08 / CT-TTg về một số nhiệm vụ, giải pháp phát triển nhanh và bền vĩng ngành công nghiệp chế biến gố và lâm sản ngoài gố phục vu xuất khẩu [Directive No. 08 / CT-TTg, March 28, 2019, Instruction on a number of tasks and solutions for fast and sustainable development of the wood and NTFP processing industry for export]. Retrieved October 31, 2019, from https://thuvienphapluat.vn/van-ban/xuat-nhapkhau/Directive-08-CT-TTg-2019-development-tasks-solutions-for-processing-industryof-timber-for-export-427208.aspx

To, P. X., Cao, C. T., Tran, H. L., Nguyen, Q. T., \& Huynh, H. V. (2019). Việt Nam xuất nhập khẩu gố 2018 một năm nhìn lại và xu huớng 2019 [Vietnam timber export-import report 2018: A look back year and trends 2019]. Retrieved April 25, 2019, from http://goviet.org.vn/bai-viet/viet-nam-xuat-nhap-khau-go-2018-mot-nam-nhin-lai-va-xuhuong-2019-8947

To, P. X., Nguyen, T. T. T., \& Nguyen, D. T. T. (2016). Một số rủi ro chính của ngành chế biến gô̂ - Xuất khẩu trong bối cảnh hội nhập - Thục trạng và Giải pháp chính sách [Some risks of export wood processing industry in the context of integration - Current situation and solutions]. Retrieved October 10, 2019, from https://trungtamwto.vn/upload/files/anpham/45-cac-an-pham-

khac/Mot\%20so\%20rui\%20ro\%20chinh\%20cua\%20nganh\%20che\%20bien\%20go\%20x uat $\% 20 \mathrm{khau} \% 20$ trong\%20boi\%20canh\%20hoi\%20nhap.pdf

White, G. (2018). European Union furniture sector scoping study - Main report. International tropical timber organization/FLEGT independent market monitor. Retrieved October 30, 2019, from http://www.flegtimm.eu/images/furniture_report/IMM_EU_furniture_sector_ scoping_study_June_27_FINAL.pdf 